\title{
Evaluation of Physiochemical Characters in Sweet Potato
}

\author{
Seema Gupta ${ }^{1 *}$, K.D. Ameta ${ }^{1}$, S. Pareek ${ }^{2}$, H.K. Jain ${ }^{1}$, D.K. Sarolia ${ }^{3}$ and S. Pilania ${ }^{1}$ \\ ${ }^{1}$ Department of Horticulture, RCA, MPUAT, Udaipur (Rajasthan)-313001, India \\ ${ }^{2}$ National Institute of Food Technology Enterpreneurship and Management, Kundli, \\ Haryana, India \\ ${ }^{3}$ Central Institute for Arid Horticulture, Bikaner, Rajasthan, India \\ *Corresponding author
}

\section{A B S T R A C T}

\begin{tabular}{|l|}
\hline K e y w o r d s \\
Sweet potato, \\
Germplasm, \\
$\begin{array}{l}\text { Physiochemical, } \beta \text { - } \\
\text { carotene, Antioxidant, } \\
\text { Tuber }\end{array}$ \\
\hline Article Info \\
\hline $\begin{array}{l}\text { Accepted: } \\
16 \text { April } 2018 \\
\text { Available Online: } \\
\text { 10 May } 2018\end{array}$ \\
\hline
\end{tabular}

\section{Introduction}

Sweet potato (Ipomoea batatas L.), an auto hexaploid species $(2 \mathrm{n}=6 \mathrm{x}=90)$ belonging to the Convolvulaceae family, is native of tropical America and normally propagated by asexual means (Veasey et al., 2007). The exact location of its botanical origin is unknown but Central America is considered the primary diversity center, while South America (Peru, Ecuador) is considered the secondary center of diversity (Zhang et al., 2000), as also is the Brazilian territory (Austin, 1988). Sweet potato is an important food crop cultivated throughout the tropics and warm temperate regions of the world for its edible storage roots. The flesh colour of the roots varies from different shades of white, cream, yellow to dark-orange depending upon the pigment present. In the orange-fleshed sweet potato (OFSP) the major carotenoid present is $\beta$-carotene, which is a precursor of vitamin A (Vimla et al., 2011).

Therefore, sweet potato has a significant role to play in the fight against vitamin $A$ deficiency (VAD). VAD is of public health significance in developing countries, causing temporary and permanent eye impairments and increased mortality, especially among children, pregnant and lactating women (Bovell-Benjamin, 2007). 
Sweet potato keeps an important place among other root and tuber crops not only for its considerable amount of nutrient, but also for phytochemicals in its root and leaves (Ji et al., 2015). Also, it has advantage of high yielding, drought tolerance and wide adaptability to various climate and farming systems over the world. A lot of variability exists among sweet potato germplasm for phytochemical character and nutritive composition which can be utilized for attaining tuber with high nutritive value. Keeping all these facts in view, the present investigation was conducted to evaluate selected improved genotypes for total soluble solids, acidity, total carotenoids and antioxidants.

\section{Materials and Methods}

The experiment was carried out at the AICRP Tuber Crops field, Department of Horticulture, Rajasthan College of Agriculture, Maharana Pratap University of Agriculture and Technology, Udaipur during 2011-2012. The experimental material comprises with sixteen diversified sweet potato germplasm and evaluated under randomized block design with three replications. Total soluble solids, acidity, total carotenoids and total antioxidants were determined after crop was harvested.

Crop was raised as per standard practices according to the package of practices for the region. The primary nursery was raised at the field of AICRP on Tuber Crops in the month of July-August. Cuttings taken from primary nursery and secondary nursery were also raised. Cuttings were taken from secondary nursery for experiment purpose. Five hundred $\mathrm{kg}$ FYM was applied at the time of preparation of the nursery. The vines were planted at a spacing of $30 \mathrm{~cm}$ on ridges formed $60 \mathrm{~cm}$ apart. Only the middle of vine with nodes was buried to $5-10 \mathrm{~cm}$ depth keeping both ends exposed. The crop was fertilized with FYM @
10 tons $\mathrm{ha}^{-1}$ as basal dose, nitrogen, phosphorus and potassium as per recommended dose which is 100:50:50 kg NPK ha ${ }^{-1}$, respectively. Half dose of nitrogen and full dose of phosphorus and potassium were applied at the time of planting while remaining half dose of nitrogen was applied one month after planting along with first weeding and earthing up.

To maintain sufficient moisture for proper establishment of the crop, a light irrigation after transplanting was applied. Sweet potato is tolerant to drought but continuous long phase of drought reduces the tuber yield. So irrigation was given 15-20 days interval. After proper establishment, sweet potato starts growing vigorously.

Therefore vines were lifted at nodes 30 days after planting to prevent rooting and to facilitate better tuber development at the basal end. First hoeing and weeding was done after 30 days of transplanting and second after 40 days of first weeding to keep plots weed free.

In order to protect the vines against incidence of sweet potato weevil (Cylas formicarius) which cause serious damage to tubers, sprays with Feninthrion $(0.05 \%)$ at monthly intervals was done. The crop was harvested manually 120 days after planting. Proper care was taken to minimize the losses during harvesting. Light irrigation 2-3 days before harvesting of tubers was given for easier digging.

\section{Total Soluble Solids (TSS)}

To determine the characteristic sample for measuring TSS, tuber flesh from three places were taken and mixed. Juice was obtained from this characteristic sample. Then the TSS content of juice was directly measured by the "Zeiss" Hand Refractometer $\left(0-30{ }^{\circ} \mathrm{B}\right)$ and value obtained were corrected at $20{ }^{\circ} \mathrm{C}$ (A.O.A.C., 2007). 


\section{Acidity (\%)}

The acidity of tuber flesh was determined by diluting the known volume of pulp with distilled water and titrating the same against standard N/10 sodium hydroxide solution, using phenolphthalein as an indicator. The appearance of light pink colour was taken as the end point. The acidity was expressed in terms of per cent acidity (A.O.A.C., 2007).

Acidity $(\%)=\frac{0.0064 \times \text { Volume of } \mathrm{NaOH} \text { use } \times 100}{\text { Volume of sampletaken }}$

\section{Total carotenoids $\left(\mathrm{mg} 100 \mathrm{~g}^{-1}\right.$ fresh weight)}

Flesh was cut into small pieces longitudinally and mixed with 80 per cent aqueous acetone for 2 hours at $50^{\circ} \mathrm{C}$ using an orbital shaker. Then it was filtered through Whatman paper. Filtrate was kept at $-20^{\circ} \mathrm{C}$ prior to analysis. Five $\mathrm{ml}$ of sample extract was mixed with 5 $\mathrm{ml}$ distill water and $1 \mathrm{ml}$ of mix (hexane/acetone/methanol) $\quad(50 / 25 / 25 \quad \mathrm{v} / \mathrm{v})$. Sample was kept at centrifuge @ 3000 rpm for $10 \mathrm{~min}$. The absorbance of upper layer was measured at $450 \mathrm{~nm}$. Total carotenoids of the sample were calculated as $\mathrm{mg} 100 \mathrm{~g}^{-1}$ (Thimmiah, 1999).

Total carotenoids $\left(\mu \mathrm{g} 100 \mathrm{~g}^{-1}\right)=\frac{A \times \text { Volume of extract }}{A^{x} \times \text { Sample weight }}$

$\mathrm{A}=$ Absorbance

$\mathrm{A}^{\mathrm{x}}=$ Absorbance coefficient (2505)

\section{Total antioxidants $\left(\mathrm{mg} 100 \mathrm{~g}^{-1}\right)$}

Five gram tuber was extracted with $20 \mathrm{ml}$ of 60 per cent methanol $(0.1 \% \mathrm{HCl})$ and kept overnight. Then it was centrifuged at 10,000 $\mathrm{rpm}$ for $15 \mathrm{~min}$ at $10^{\circ} \mathrm{C}$. The supernatant was taken for analysis. Hundred $\mu \mathrm{l}$ of methanolic extract was mixed with $3 \mathrm{ml}$ of solution (1.2 M sulphuric acid, $46 \mathrm{mM}$ sodium phosphate and $8 \mathrm{mM}$ ammonium molybetate) and was incubated for $90 \mathrm{~min}$ at $95^{\circ} \mathrm{C}$ in water bath. It was then allowed to cool down at room temperature. Reading of plant sample was read using spectrophotometer at a wavelength of $695 \mathrm{~nm}$ and ascorbic acid was taken as standard. Standard curve was plotted with the absorbance readings of standard and plant sample which gave value of total antioxidant in $\mathrm{mg}^{100 \mathrm{~g}^{-1}}$ (Thimmiah, 1999).

\section{Results and Discussion}

\section{TSS and Acidity}

There were highly significantly differences among germplasm for TSS which ranged from $2.20\left({ }^{\circ} \mathrm{B}\right)$ to $4.10\left({ }^{\circ} \mathrm{B}\right)$ being minimum in 'ST14 ' and maximum in 'Sree Ratna'. Likewise, highly significant differences were exhibited among germplsm for acidity. Results were supported by Ali et al., (2015a) and Ali et al., (2015b) (Table 1 and 2).

\section{Total carotenoids (mg $100 \mathrm{~g}^{-1}$ fresh weight), total antioxidants (mg $100 \mathrm{~g}^{-1}$ fresh weight)}

The study revealed significant differences for total carotenoid in sweet potato germplasm. Total carotenoids ranged from $0.55 \quad(\mathrm{mg}$ $100 \mathrm{~g}^{-1}$ fresh weight) to $4.27\left(\mathrm{mg}^{100 \mathrm{~g}^{-1}}\right.$ fresh weight) being minimum in 'POL-19-8-10' and maximum in 'CIPSWA-2'. Kathabwalika et al., (2016) also reported similar results. The variations within genotype would be a result of genetic make-up of the cultivars in the synthesis of the carotenoids (RodriguezAmaya and Kimura, 2004). Some genotype produces more beta-carotene than others due to the difference in their genetic makeup. Saikia et al., (2009) also reported carotenoids content in orange fleshed sweet potato cultivars. Onwueme (1978) and Lila Babu (1988) reported that sweet potato contains 1$12 \mathrm{mg}$ carotene $100 \mathrm{~g}^{-1}$ of tuber. According to Ezell and Wilcox (1946) and Vimla et al., (2011) cultivar differences, seasonal changes, stage of maturity, storage time and conditions after harvest etc., are responsible for variation in $\beta$-carotene content among clones (Table 3 ). 
Table.1 Detail of germplasm and their source

\begin{tabular}{|l|l|l|} 
S. No. & \multicolumn{1}{|c|}{ Name } & \multicolumn{1}{c|}{ Source } \\
\hline 1 & CIPSWA-2 & World Potato Regional Centre, New Delhi \\
\hline $\mathbf{2}$ & CO-3-4 & CTCRI, Thiruvananthapuram \\
\hline $\mathbf{3}$ & Gauri & CTCRI Regional Centre, Bhubaneshwar \\
\hline $\mathbf{4}$ & Gautam & CTCRI Regional Centre, Bhubaneshwar \\
\hline $\mathbf{5}$ & H-109-2 & Navsari Agricultural University, Navsari \\
\hline $\mathbf{6}$ & Navsari Local & Navsari Agricultural University, Navsari \\
\hline $\mathbf{7}$ & Pol-19-8-10 & CARI, Port Blair \\
\hline $\mathbf{8}$ & Samrat & CTCRI, Thiruvananthapuram \\
\hline $\mathbf{9}$ & SI-1 & Navsari Agricultural University, Navsari \\
\hline 10 & Sree Arun & CTCRI, Thiruvananthapuram \\
\hline $\mathbf{1 1}$ & Sree Nandini & CTCRI, Thiruvananthapuram \\
\hline $\mathbf{1 2}$ & Sree Ratna & CTCRI, Thiruvananthapuram \\
\hline $\mathbf{1 3}$ & Sree Vardhini & CTCRI, Thiruvananthapuram \\
\hline $\mathbf{1 4}$ & ST-10 & CTCRI, Thiruvananthapuram \\
\hline $\mathbf{1 5}$ & ST-14 & CTCRI, Thiruvananthapuram \\
\hline 16 & SV-71 & BCKV, Kalyani \\
\hline
\end{tabular}

Table. 2 TSS $\left({ }^{\circ} \mathrm{B}\right)$ and acidity (\%) in sweet potato tubers

\begin{tabular}{|l|}
\hline Genotype \\
\hline CIPSWA-2 \\
\hline CO-3-4 \\
\hline Gauri \\
\hline Gautam \\
\hline H-109-2 \\
\hline Navsari Local \\
\hline POL-19-8-10 \\
\hline Sree Nandini \\
\hline Sree Vardhini \\
\hline Samrat \\
\hline SI-1 \\
\hline Sree Arun \\
\hline Sree Ratna \\
\hline ST-10 \\
\hline ST-14 \\
\hline SV-71 \\
\hline Mean \\
\hline Range \\
\hline SEm \pm \\
\hline CD (P=0.05) \\
\hline CV (\%) \\
\hline
\end{tabular}

\begin{tabular}{|c|c|}
\hline TSS $\left({ }^{\circ} \mathbf{B}\right)$ & Acidity $(\%)$ \\
\hline 2.77 & 0.13 \\
\hline 2.50 & 0.32 \\
\hline 2.67 & 0.45 \\
\hline 2.70 & 0.38 \\
\hline 3.03 & 0.26 \\
\hline 3.20 & 0.32 \\
\hline 2.90 & 0.26 \\
\hline 3.30 & 0.26 \\
\hline 3.81 & 0.19 \\
\hline 3.20 & 0.44 \\
\hline 3.50 & 0.19 \\
\hline 2.50 & 0.13 \\
\hline 4.10 & 0.13 \\
\hline 3.60 & 0.32 \\
\hline 2.20 & 0.32 \\
\hline 3.80 & 0.26 \\
\hline 3.10 & 0.29 \\
\hline $2.20-4.10$ & $0.13-0.45$ \\
\hline 0.11 & 0.01 \\
\hline 0.33 & 0.03 \\
\hline 6.30 & 5.27 \\
\hline & \\
\hline
\end{tabular}


Table.3 Total carotenoids (mg $100 \mathrm{~g}^{-1}$ fresh weight) and total antioxidants (mg $100 \mathrm{~g}^{-1}$ fresh weight) in sweet potato tubers

\begin{tabular}{|l|c|c|}
\hline Genotype & $\begin{array}{c}\text { Total Carotenoids } \\
\left(\mathbf{m g}^{-1} \text { fresh weight) }\right.\end{array}$ & $\begin{array}{c}\text { Total Antioxidants } \\
\left(\mathbf{m g ~ 1 0 0 g ^ { - 1 }} \text { fresh weight) }\right.\end{array}$ \\
\hline CIPSWA-2 & 4.27 & 0.23 \\
\hline CO-3-4 & 0.82 & 0.27 \\
\hline Gauri & 3.45 & 0.23 \\
\hline Gautam & 1.56 & 0.24 \\
\hline H-109-2 & 3.94 & 0.28 \\
\hline Navsari Local & 1.04 & 0.18 \\
\hline POL-19-8-10 & 0.55 & 0.21 \\
\hline Samrat & 0.63 & 0.31 \\
\hline SI-1 & 2.49 & 0.19 \\
\hline Sree Arun & 3.52 & 0.25 \\
\hline Sree Nandini & 0.76 & 0.26 \\
\hline Sree Ratna & 0.85 & 0.21 \\
\hline Sree Vardhini & 0.87 & 0.19 \\
\hline ST-10 & 1.01 & 0.28 \\
\hline ST-14 & 2.60 & 0.25 \\
\hline SV-71 & 1.17 & 0.19 \\
\hline Mean & 1.84 & 0.24 \\
\hline Range & $0.55-4.27$ & $0.18-0.31$ \\
\hline SEm \pm & 0.09 & 0.009 \\
\hline CD (0.05) & 0.26 & 0.03 \\
\hline CV (\%) & 8.38 & 6.60 \\
\hline
\end{tabular}

Result of this study also showed significant differences among sweet potato germplasm for total antioxidants which ranged from 0.18 (mg $100 \mathrm{~g}^{-1}$ fresh weight) to $0.31\left(\mathrm{mg} 100 \mathrm{~g}^{-1}\right.$ fresh weight). High phenolic content in sweet potato germplasm might be responsible for significantly higher antioxidant activities (Ji et al., 2015).

\section{Acknowledgement}

The Authors hereby acknowledge the support of the Cetere of Tuber Crop Research Institute for providing germplasm and Rajasthan College of Agriculture, Maharana Pratap University of Agriculture and Technology, Udaipur for financing the research.

\section{References}

A.O.A.C. 2007. Official Method of Analysis. $15^{\text {th }}$ Ed. Vol 2. Association of Official Analytical Chemists, Washington, D.C.

Ali, S., Mohammed, W. and Shimelis, B. 2015a. Agronomic and physiochemical evaluation of sweet potato (Ipomoea batatas L.) collections in Ethiopia. Advances in Crop Science and Technology. 3(3): 172/23298863.1000172.

Ali, S., Mohammed, W. and Shimelis, B. 2015b. Evaluation of sweet potato (Ipomoea batatas L.) accessions for their physiochemical attributes in 
Ethiopia. International Journal of African and Asian Studies. 15: 49-54.

Austin, D.F., 1988. The taxonomy and genetic diversity of sweet potatoes and related wild species. In: Sweet Potato Planning Conference, Exploration, maintenance and utilization of sweet potato genetic resources-report. 369.

Bowell-Benjamin, A.C., 2007. Sweet potato: A review of its past, present and future role in human nutrition. Advances in Food and Nutrition Research. 52: 1-58.

Ezell, B.D. and Wilcox, M.S., 1946. The ratio of carotene to carotenoids pigments in sweet potato varieties. Scientia.103: 193-194.

Ji, H., Zhang, H., Li, H. and Li, Y., 2015. Analysis on the nutrient composition and antioxidant activity of different types of sweet potato cultivars. Food and Nutrition Sciences.6: 161-167.

Kathabwalika, D.M., Chilembwe, E. H.C. and Mwale, V. M. 2016. Evaluation of dry matter, starch and beta-carotene content in orange-fleshed sweet potato (Ipomoea batatas L) genotypes tested in three agro-ecological zones of Malawi. African Journal of Food Science. 10(1): 320-326.

Lila, B. 1988. Biochemical constituent of sweet potato. First International Training Course on Sweet Potato Production, 8-13 August, 1988. CTCRI, Thiruvanantpuram, India. pp. 111-113.
Onwueme, I.C. 1978. The Tropical Tuber Crops, John Willey and Son's, New York. pp. 168-171.

Rodriguez-Amaya, D.B. and Kimura, M., 2004. Harvest plus handbook for carotenoid analysis. Harvestplus Technical Monographic. 2, Washington D.C. and Cali, Columbia. P.3.

Saikia, J., Borah, P. and Nath, D.K. 2009. Evaluation of few carotene rich sweet potato genotypes under Assam conditions. Journal of Root Crops. 35: 232-235.

Thimmiah, S.R. 1999. Estmation of chlorophyll. In: Standard Method of Chemical Analysis. Kalyani Publisher. Pp. 307.

Veasey, E. A., Silva, J.R.Q., Rosa, M.R., Borges, A., Bressan, E.A. and Peroni, N. 2007. Phenology and morphological diversity of sweet potato (ipomoea batatas L.) landraces of the Vale Do Ribeira. Scientia Agriculture. 64(4): 416-417.

Vimla, B., Nambisan, B. and Hariprakash, B. 2011. Variability of carotenoids and dry matter content in orange-fleshed sweet potato during storage. Journal of Root Crops. 37: 182-185.

Zhang, D., Cervantes, J., Huaman, Z., Carey, E., Ghislain, M. 2000. Assessing genetic diversity of sweet potato (Ipomoea batatas L.) cultivars from tropical America using AFLP. Genetic Resources and Crop Evaluation. 47: 659-665.

\section{How to cite this article:}

Seema Gupta, K.D. Ameta, S. Pareek, H.K. Jain, D.K. Sarolia and Pilania, S. 2018. Evaluation of Physiochemical Characters in Sweet Potato. Int.J.Curr.Microbiol.App.Sci. 7(05): 1000-1005. doi: https://doi.org/10.20546/ijcmas.2018.705.124 